\title{
THE UNITED STATES AND THE DECLARATION OF PARIS.
}

The YALE LAW JouRnal for February contains an interesting article by Professor Theodore S. Woolsey, with the above title. The article commences with the observation that-"There is a probability that the accession of the United States to the Declaration of Paris" (of $185^{6}$ ) "is shortly to be urged upon the Secretary of State." This Declaration, as is well known, begins with the proposition - "Privateering is and remains abolished;" and it is with special reference to the renunciation by our government of the right of privateering that its accession to the Declaration is urged by the writer. He concludes that if such accession "is a proper step, it should be taken now."

The step may be quite proper in the sense of being expedient, but still not really proper because the law does not sanction it. Conceding all the objections to privateering, there must yet always be a serious legal obstacle to our joining in an international agreement that "privateering is and remains abolished." This obstacle is presented by our very organic law itself, the Constitution. That instrument, in Article I., Section 8, expressly authorizes privateering, and contemplates a resort to it, without limitation as to time or occasion (except inferentially that the occasion shall be war), by empowering Congress, in general terms, "to grant letters of marque and reprisal." The power given is a part of the War Power of Congress; the entire provision being- "The Congress shall have Power * * * to declare War, grant Letters of Marque and Reprisal, and make Rules concerning Captures on Land and Water." Of course no legislative nor executive act can avail to do away with or modify a constitutional provision, or divest or impair a constitutional power. Nor can treaty, which possesses no higher legal force than statute, ${ }^{1}$ have any such effect. As the Supreme Court observes in an adjudged case :2 "It need hardly be said that a treaty cannot change the Constitution, or be held valid if it be in violation of that instrument." (Indeed the stipulation, which has appeared in some of our treaties, by which

1 Sec. I3 Opins. of Attys. Gen. 354.

2 The Cherokee Tobacco, iI Wallace 620. 
the United States agrees, mutually with the other party, to surrender the right of privateering, is, in my judgment, clearly an assumption of authority in contravention of the Constitution).

Thus, should the United States, in the future, be induced in any form to accede to the Declaration of Paris, or other public predication by which privateering is in terms renounced or "abolished," the power to commission privateers, as vested by the Constitution, would remain intact. No subsequent Congress could be bound by such an enunciation. At any later date, when political conditions were wholly changed-when a war had been initiated or was impending-Congress could freely, as it did in our earlier wars, exercise the power, and that it would exercise it is not at all improbable. Even in our late civil war, when hostilities at sea were scarcely anticipated, Congress, by an Act of March 3, r863, authorized the President " to issue, to private armed vessels of the United States, commissions or letters of marque and general reprisal, in such form as he shall think proper and under the seal of the United States, and to make all needful rules and regulations for the government and conduct thereof and for the adjudication and disposal of the prizes and salvages made by such vessels." Much more, it would seem, would the power be likely to be exerted in the presence of a conflict with a state having a formidable navy.

I concur, indeed, with Professor Woolsey that because of the modern improvements in naval steamers, especially the introduction of "fast cruisers with large coal capacity," there must be less occasion than formerly for a recourse to privateers. I do not however so readily admit his premise that the United States is more likely to become involved in war with a state "weaker in naval resources than itself than with one stronger." Our people might well consider it cowardly for this great republic to engage in hostilities with a weak nation, while it would be bold or rash enough to tackle in war the most powerful if the provocation appeared to warrant it. But, however this all may be, it is certainly among the probabilities that, in the face of a contest impending with any considerable maritime power, Congress, in availing itself of the weapons placed in its hands, would be induced to extend to its enterprising sea-faring citizens the opportunities of the privateer. Though a service less attractive perhaps than heretofore, it would still be popular with many, and the emergency would justify it.

But whether an exercise in the future by Congress of the power to employ privateering be probable or improbable is really 
immaterial. It is enough that the power subsists capable at any fit time of being called into execution, and while it subsists with what reason could the United States proclaim that privateering was no longer possible, was extinct? Under the circumstances, would not its part of the manifesto be mere ostentation, vain words? For a government to make formal announcement of the absolute abrogation of a specific provision of its public law when that provision still endures in full virtue as from the beginning, would involve a bald contradiction and a fraud. So to assume to declare that a certain legitimate mode or means of warfare "is and remains. abolished," when it is not abolished in fact, and cannot be abolished without a proceeding beyond the reach and furction of the declarant-without a due and formal constitutional amendment which has not yet been even attempted-would be as futile as it would be irrational. Conceding; as before remarked, all the grounds why privateering should not exist, the fact that a continuing power to make it exist resides in proprio vigore in the charter, as one of our original constitutional resources, should certainly be sufficient to deter our government from promulgating its nonexistence to the world.

Thus, in the absence of an amendment of the Constitution by which the power under consideration shall be stricken from the enumeration of its express grants - and such an amendment can scarcely be anticipated as a possibility-it is believed to be demonstrated that there can legally be no accession by the United States to the first article of the Declaration.

It may be observed that the Convention of Paris did not assert that privateering ought to be abolished, but that it was abolished, finally and permanently. Should our government, in the future, join in or initiate a proposition that privateering ought to be abolished, while at the same time taking measures to launch a constitutional amendment divesting the existing power of Congress over the subject, its action would be consistent and a moral effect might be produced. But a coincidence so improbable need not be dwelt upon.

The difficulty in which this subject is involved lies simply in the fact that we have a written constitution. A nation with a written constitution of defined powers and rights must often find itself hampered in entering into positive declarations of principle or policy with nations not thus embarrassed, and whose legislature or executive is practically supreme. 